\title{
LEARNING EXPERIENCE AS A FACTOR OF MOTIVATION IN LOWER-SECONDARY SCHOOL IN FOREIGN LANGUAGE LEARNING
}

\author{
Eva Stranovská, Anikó Ficzere, Silvia Hvozdíková, Beáta Hockicková \\ Constantine the Philosopher University, Slovakia \\ E-mail: estranovska@ukf.sk, aniko.ficzere@ukf.sk, shvozdikova@ukf.sk, \\ bhockickova@ukf.sk
}

\begin{abstract}
This research focusses on the analysis of learning experience. Together with the other factors of motivational structure: Intrinsic motivation, Personal goals, Attractivity of foreign language community, and Worries about learning, it creates motivational profile of foreign language (FL) learners. The analysis is based on the theoretical concept of foreign language motivational self-system by Dörnyei.

The research aim was to find out the perception of learning experience and the level of its dependence on the category of the Associations with the expression "German" in the selected categories. Moreover, it was to find out the differences in perception of learning experience, motivational structure, and the length of foreign language studying. The research sample consisted of German FL learners from six different lower-secondary schools within Slovakia. Motivational Structure Questionnaire was used as a research tool to obtain the research data. The data were processed by the selected quantitative and qualitative research methods. The research results supported ambivalence of learning experience.

The statistical significance was found in the two categories: the category of Negative emotions related to the category negative perception of educational situation, and the category of German speaking countries related to the higher level of motivation in the factor of learning experience. Furthermore, significant relations were found between the factor of learning experience and the factors of the ideal self of the motivational structure and the length of studying a foreign language. The results in the qualitative part of the research opened up a possible intervention steps towards foreign language motivation reinforcement. Keywords: foreign language, learning experience, motivation in education, qualitative research methods, quantitative research methods.
\end{abstract}

\section{Introduction}

Motivation is the primary predictor of educational process and is an inevitable element of positive educational achievements. When teachers and learners share the same educational interests, they may create an authentic product, achieve success in educational process and come to the point of positive learning experience. The factor of positive learning experience plays an essential role in the process of motivation in education. Prominently because of positive perception of educational process, relationship to teacher and other learners, social dynamics, atmosphere, educational content, experience of success or unsuccess and other variables create experiential continuum of learners and their learning experience.

Many scientific studies emphasized learning experience in the process of education in the seventies of the 20th century. Kolb (1970, in Sarmány-Schuller, 1992) highlighted the premise that the process of education is also derived from learner's experience and is formed within four-stages. Oravcová (2000), Stranovská (2009), Kaliská (2013) and others 
Eva STRANOVSKÁ, Anikó FICZERE, Silvia HVOZDÍKOVÁ, Beáta HOCKICKOVÁ. Learning experience as a factor of motivation in lower-secondary school in foreign language learning

IN THE $21^{\text {st }}$ CENTURY Vol. 77, No. 3, 2019

438

have verified the theory in the recent studies. The main emphasis of the studies was selfregulation of learning, development of the personality of the learner where learners regulate their own learning processes. Learning experience has an original position in the process of foreign language learning because there are many uncertain ambiguous situations involved in the process. It is not possible to learn them by heart or expect exactly how they happen. There are many situational factors involved, for example, foreign language attractivity, foreign language cultural perception, experience with a foreign language culture, different cultural patterns, including cultural background of the mother tongue. The variable has not been studied in relation to the motivational structure into such extent. The factor of motivational structure has been studied mainly in relation to intrinsic and extrinsic motivation (Deci, \& Ryan, 1993; Dörnyei, 2001; Gardner, 1985; Riemer, 2003). The studies emphasising intrinsic and extrinsic motivation in relation to success in language education were led by Janíková (2011), Dunowski (2015). Currently, the studies have emphasised motivation and self-efficacy, self-perception (Dörnyei, 2014; Riemer, 2010) in relation to classroom management (Butt, Ahmad, \& Ghazala, 2010) and others. The direction of motivational models' research has been redirected to a wider range of dimensions. Currently, they focus on learning experience in foreign language learning. The motivational theories intend to capture complexity of motivational structure.

The emphasis of this research aimed at learning experience in relation to motivational structure of learners, specifically, intrinsic motivation, personal goals, attractivity of FL community, worries about learning. It was a multidimensional research encompassing subjective feeling of success of learning German language, perception of personal relationship to teacher, perception of knowledge by others. The aim of the research was to analyse learning experience dimension and its impact on the perception of meaning of the expression German. Moreover, it was to find correlations between learning experience, motivational structure, and years spent by learning German language.

\section{Motivational Theories and Learning Experience in Relation to Foreign Language Education}

Several experts in language education claimed the shift of perception of the motivation concept in education in the 90s, (see Dörnyei, 2014; Kirchner, 2004; Riemer, 2003). The importance of motivation in education has risen. The experts agreed on the essential role of motivation as the most accessible determinant in the process of language acquisition, language learning and teaching of foreign language. The amount of qualitative models of research has risen. They pointed out the importance of interpersonal variability in the dimension. Several studies confirmed the differences in the perception of motivation between the individuals as well as in relation to the length of study. The studies confirmed the decreased levels of motivation in the later years of studying the language (Juhásová, 2016; Riemer, 2003). In order to reflect the dynamic character of motivation, it was essential to provide new models of motivation. The new theoretical constructs integrated earlier knowledge as well as explanation of the situational impact, and wider individual differences in motivation.

The social and educational theory of motivation by R. C. Gardner dominated in the 70s. Based on the attitude towards language and language community there are two elementary types of motivation (Masgoret, \& Gardner, 2003). Integrative orientation is demonstrated by the interest about the culture, the country, the people, and the community of the target language. In opposition, there is an instrumental motivation demonstrated by the practical use of achieved knowledge. Gardner's theory points out social dimension of foreign language acquisition, a learner compares himself/herself with the language community and culture (Kirchner, 2004).

Deci and Ryan (1993) defined motivation as a continuum. The beginning and the final two points are the intrinsic and the extrinsic motivation. The intrinsic motivation is demonstrated by 
curiosity, spontaneity and interest. The external motivation is summonned by external tasks, the

challenges from the external world. It is called self-determined motivation theory.

Earlier theories determined motivation as a subjective category. They highlighted the importance of one dimension and put the two points in opposition, out of which only one alternative was acceptable, wanted, for example, integrative against instrumental, intrinsic against extrinsic motivation. They explained the positive aspect of motivation as an internal conviction having nothing in common with the conditions of external social environment. The external agents were perceived as less important aspects of motivation (Deci, \& Ryan, 1993; Kirchner, 2004; Masgoret, \& Gardner, 2003). Also today a very often approach to the motivation in relation to teaching and learning processes is to stress it as one of the key tasks of the teacher professional performance (Gadušová, \& Hašková, 2016, 2017; Hašková, \& Dovalová, 2017; Štúr, 2018).

In the current research studies motivation is defined as an attribution theory. Attributes are cognitive processes. Learners use them to explain their success/unsuccess. Kirchner (2004) considered the following as the most important attributes in relation to motivation:

- Searching for reasons of (un)success in themselves or in the others

- Considering the reasons as stable or changeable

- Accepting responsibility for the changes or redirecting responsibility to other people.

Based on The Theory of Attribution by Kirchner (Kirchner, 2004) it is possible to expect higher levels of willingness to direct his/her own education when learners perceive the reasons of their success mostly in the internal factors.

Considering methodology the research was rooted in the precise concept developed by Dörnyei (2014). The model of foreign language FL motivational self-system emphasises dynamic character of motivation integrating a variety of earlier motivational theories. Dörnyei presupposes existence of possible selves, which play essential roles in the educational process. The possible selves are the lively images about oneself in the future. According to Dörnyei (2014) the ideal FL self ought-to-self play the key role in the system of selves. The ideal self includes the set of goals. The concept of ought-to-self responses to the images is about the expectations and responsibilities.

Dörnyei (2014) defined the term learning experience as the third dimension of motivational self-system. It was defined as a "learner's situation-specific motives related to the immediate learning environment and experience"(Dörnyei, 2014, p. 521). The dimension of learning experience includes the previous experience gained from the language acquisition process and reflects social situation in the classroom during the process. Together with the cognitive, intrapersonal attributes, it is tightly related to social level of learning, specifically, the relationships learner-teacher, learner-learner, and the social dynamics in the classroom. Furthermore, one of the essential aspects of learning experience is the experience of success in foreign language education. The model directed attention to the notion of aims and supported teachers to encourage their students to develop systematic, long-term and positive selfrepresentations in relation to foreign language learning. The current theory intends to explain complexity of motivational structure of an individual and is placed in the system of external educational environment agents.

Stranovská (2011) defined important determinants of motivation, for example, the elements of social environment, social interaction in the classroom, the teacher-learner relationship, and the factors of further social character, such as traditions, culture, and habits. Lalinská (2014), Lalinská, Scheer (2014), Kondrla, Králik (2016) and Králik, Lenovsky, Pavlikova (2018) emphasised the importance of further social character, specifically, culture in the process of motivation. The essential elements of the motivational self-system by Dörnyei (2014) are the previous FL experience taken from the social world. 
Eva STRANOVSKÁ, Anikó FICZERE, Silvia HVOZDÍKOVÁ, Beáta HOCKICKOVÁ. Learning experience as a factor of motivation in lower-secondary school in foreign language learning

$$
\begin{array}{r}
\text { PROBLEMS } \\
\text { OF EDUCATION } \\
\text { IN THE 21 }{ }^{\text {st }} \text { CENTURY } \\
\text { Vol. 77, No. 3, } 2019 \\
\hline 440
\end{array}
$$

Problem of Research and Research Focus

Although there is a number of research studies dealing with the importance of the motifs of the ideal and ought-to self, the research studies covering the issues of learning experience are less apparent. Many times more factors unexpectedly enter the situation - also called ambiguity - to the process of foreign language learning. Apparently, it is difficult to anticipate their characteristics, content or to train the responses precisely. Probably, internal processing of such ambiguous situations is reflected in the specific learning experience of an individual influence on his/her overall motivation and his/her perception of the studied language and its culture. That is why this research specifies the difference in the perception of learning experience in relation to the meaning of the word German in the selected research categories. In this research the relation between the categories of learning experience, motivational structure and the length of studying a foreign language was examined. This research is based on the findings of the current theories and examines motivation in a wider social context.

The following hypotheses were formulated with the examined categories: 1. Learning experience, 2. Dimensions of motivational structure:

$\mathrm{H}_{1}$ : A positive relation is assumed between learning experience and the selected dimensions of motivational structure.

$\mathrm{H}_{2:}$ A negative relation is assumed between learning experience and length of studying German language.

$\mathrm{H}_{3:}$ Perception of learning experience varies in relation to the meaning of the expression German and depends on the categories Foreign language, Complexity, German speaking countries, and Negative feelings.

\section{Research Methodology}

\section{General Background}

This research was carried out at lower-secondary schools in Slovakia during the school years of 2017, 2018. Although, the prevailing approach to the research was qualitative, the quantitative analysis was also applied.

The motivational structure was operationalised as follows:

1. Intrinsic motivation -into what extent the learners are willing to learn German language only to become wiser, know more.

2. Personal goals - into what extent learners consider German language knowledge as important, as a part of future vocational development, as a part of preparation for working abroad.

3. Attractivity of FL community - learners manifest their interest about FL community, intend to develop relationships with the people from foreign community, considering the German countries as the important subjects in the world matter.

4. Worries about learning - learners worry about their negative academic achievements, about their parents` expectations.

5. Learning experience - the factors related to the experience of learning FL in the classroom.

The central variable of learning experience consisted of the following items:

1. Extent of subjective feeling of success when using German language in the classroom,

2. Personal teacher-learner relationship perception,

3. How (the others) the classmates accept FL knowledge of the selected learners. 
Eva STRANOVSKÁ, Anikó FICZERE, Silvia HVOZDÍKOVÁ, Beáta HOCKICKOVÁ. Learning experience as a factor of motivation in lower-secondary school in foreign language learning

\section{Research Sample}

The sample consisted of 84 Slovak learners studying German as a foreign language at the lower-secondary schools (Table 1). The respondents were selected randomly from the lowersecondary schools in the region of Nitra, Slovakia. Six schools were selected for this research, each school was represented by one class of eighth graders; together there were 84 learners. The respondents were 14-15 years old German language students. They had been studying German language during the time span of 2 to 4 years. The proficiency level of the learners speaking German as a foreign language was A1 and A2 (as represented in the frame of CEFR). The selection of the sample was limited to the region of Nitra in the south-west of the country. The sample had been monitored during the period of the years 2017-2018 as a part of the Research Project (see the Acknowledgements). Except German, other foreign languages (French and English) were also examined. The number of German as foreign language students was limited by the number of the students available within the selected schools.

The research did not have any impact on the assessment of the individual learners, neither the learners` identities were recorded in any form.

Table 1. Description of the research sample

\begin{tabular}{ll}
\hline Gender & 43 female adolescents, 41 male adolescents \\
\hline Number of learners of selected schools & $\begin{array}{l}1^{\text {st }} \text { school: } 14 \text { learners, } 2 \text { nd school: } 11 \text { learners, 3rd school: } 18 \text { learners, } \\
4 \text { th school: } 13 \text { learners, } 5^{\text {th }} \text { school: } 15 \text { learners, } 6 \text { th } \text { school: } 13 \text { learners }\end{array}$ \\
\hline Length of study of German language & 44 learners: 2 years, 29 learners: 3 years, 11 learners: 4 years \\
\hline
\end{tabular}

\section{Instruments and Procedure}

The motivational structure of learners and their associations to German language as a foreign language were measured by the Questionnaire of Motivational Structure designed by Dörnyei and Csizér (2002), adapted for the purpose of the research. It consisted of 12 items including the dimensions of motivational structure, specified in the section General background. The three items of the questionnaire measured the dimension learning experience. 7-point Likert scale was used to get the responses. There was also one open question used asking the respondents to express their own associations with the expression German.

The responses to the open question were coded by the categorical system, defined on the bases of the empirical material designed specifically for the purpose of the research. The categories for the content analysis were the following:

1. Foreign language - learners claimed German as a foreign language

2. Complexity - subjective impression of complexity of several areas of German language system,

3. German speaking countries - name a German speaking country,

4. Negative feelings - implicit or explicit negatively verbalised feelings.

\section{Data Analysis}

The descriptive statistics was used for the purpose of the statistical processing and the analysis of the collected data. The focus was laid on the description of basic statistical indicators (mean, percentual mean, minimum, maximum, median, standard deviation). Descriptive analysis was further applied in the three selected questions of the Motivational Structure Questionnaire measuring the dimension of learning experience. In order to examine 
Eva STRANOVSKÁ, Anikó FICZERE, Silvia HVOZDÍKOVÁ, Beáta HOCKICKOVÁ. Learning experience as a factor of motivation in lower-secondary school in foreign language learning

PROBLEMS

OF EDUCATION

IN THE $21^{\text {st }}$ CENTURY Vol. 77, No. 3, 2019

442

the correlation between learning experience, the dimensions of motivational structure, and the years of studying, Spearman correlation was used.

Considering the open question four categories of associations were tested. The categories were as follows: Foreign language, Complexity, German speaking countries, Negative feelings. When the tested categories occurred in the responses for $20 \%$ of the respondents the variance analysis ANOVA was used to test the difference in learning experience. The respondents were divided into three categories based on the occurrence of the selected associations: 1) The group of the respondents without the tested associations, 2) The respondents with one association in the given category, 3) The respondents with multi-occurrence of the association in the category. The difference of the average in the learning experience dimension was tested by the variance analysis.

\section{Research Results}

Table 2 displays the results of descriptive analysis of the motivational structure dimension in the group of the selected respondents. The arithmetic mean of the dimensions of Attractivity of FL community, the Personal goals, and the Worries appeared to be the most frequent motivational factors in the foreign language learning (the average was over $65 \%$ ). The factors of Intrinsic motivation and Learning experience appeared as less motivating dimensions. The factor of Learning experience achieved the lowest possible percentage values (the average was $51.5 \%$ ).

Table 2. Descriptive results of the motivational structure dimensions.

\begin{tabular}{llllll}
\hline Variable & IM & PG & ALC & W & LE \\
\hline Mean & 8.429 & 9.19 & 9.119 & 9.131 & 10.81 \\
\hline Mean\% & 60.2 & 65.6 & 65.1 & 65.2 & 51.5 \\
\hline Median & 8,5 & 9.5 & 9 & 9 & 11 \\
\hline Standard deviation & 3.697 & 3.209 & 2.926 & 3.505 & 4.306 \\
\hline Minimum & 2 & 2 & 2 & 2 & 3 \\
\hline Maximum & 14 & 14 & 14 & 14 & 20 \\
\hline
\end{tabular}

Explanations: Motivational structure dimensions IM - Intrinsic motivation, PG - personal goals, AlC attractivity of language community, $W$-worries about learning, $L E$-learning experience.

The items of the dimension learning experience are displayed in Table 3. Positive learning experience occurred in the lowest possible extent in the question Q2 - acceptance of language knowledge by the classmates (arithmetical mean 36.6\%), the highest in the question Q7 - personal relationship to the teacher perception and Q12 - the extent of subjective feeling of success in German language in the classroom (arithmetical means 59.7\% a 58.2\%). The opinions of the respondents were divergent, answering to the question Q7 - personal relationship to the teacher perception (standard deviation 2.528)

Table 3. Descriptive results of the items of the dimension learning experience.

\begin{tabular}{llll}
\hline Variable & Q2 & Q7 & Q12 \\
\hline Mean & 2.560 & 4.179 & 4.071 \\
\hline Mean\% & 36.6 & 59.7 & 58.2 \\
\hline Median & 2 & 4 & 4 \\
\hline Standard deviation & 1.623 & 2.528 & 1.925 \\
\hline Minimum & 1 & 1 & 1 \\
\hline Maximum & 7 & 7 & 7 \\
\hline
\end{tabular}


Eva STRANOVSKÁ, Anikó FICZERE, Silvia HVOZDÍKOVÁ, Beáta HOCKICKOVÁ. Learning experience as a factor of motivation in lower-secondary school in foreign language learning

Learning experience dimension: Q2 - acceptance of the knowledge by the classmates, $Q 7$ - perception of the relationship to the teacher, Q12 - the feeling of success in German language.

PROBLEMS

OF EDUCATION

IN THE $21^{\text {st }}$ CENTURY

Vol. 77, No. 3, 2019

In order to test the research hypotheses, the Spearman correlation was used. It examined the relations between learning experience and the motivational structure. The same method was applied to test the relations between the dimension of learning experience and the length of FL study. The results are presented in Table 4. Analysis supported the hypothesis about the positive relations between the factor learning experience and the dimensions of motivational structures, specifically, the factor of intrinsic motivation ( $\left.p=.001^{* * *}\right)$, attractivity of FL community ( $p=$ $.042 *)$, and personal goals $(\mathrm{p}=.0001 * * *)$. The correlation was not confirmed in the case of the dimension Worries. Moreover, the results of the analysis confirmed negative relation between learning experience and the dimension years of studying the language $(\mathrm{p}=.022 *)$.

Table 4. The results of correlations (Spearman rho) between the dimension of learning experience and the other motivational structure dimension specifically, the years of studying the language.

\begin{tabular}{lllllll}
\hline & \multicolumn{1}{c}{$\begin{array}{c}\text { Study } \\
\text { years }\end{array}$} & IM & ALC & PG & W \\
\hline \multirow{2}{*}{ LE } & Correlation Coefficient & -.250 & .351 & .223 & .411 & .016 \\
\cline { 2 - 6 } & Significance (2-tailed) & $.022^{*}$ & $.001^{* * *}$ & $.042^{*}$ & $.0001^{* * *}$ & .882
\end{tabular}

The values of statistical significance $p=.05\left(^{*}\right), p=.01\left(^{* *}\right), p=.001\left(^{* * *}\right)$

IM-intrinsic motivation, PG-personal goals, ALC-attractivity of language community, W-worries about learning, $L E$ - learning experience

The motivational dimension of learning experience was tested in relation to word association of the word German. The variance analysis ANOVA was used to test the interaction between the selected groups of answers and the dimension of learning experience. The analysis was processed in the following categories: Negative feelings, Language complexity, Foreign language, German-speaking countries. Considering the categories language complexity and foreign language, no statistically significant difference in the motivational dimension of learning experience was found. However, there were statistically significant differences found considering the other two categories as presented in the selected groups of the respondents: negative feelings and German speaking countries as displayed in the Table 5. Although negative feelings were related to the negative perception of educational situation as the variance analysis showed, the category German speaking countries were closely related to the higher extent of motivational dimension of learning experience. 
Eva STRANOVSKÁ, Anikó FICZERE, Silvia HVOZDÍKOVÁ, Beáta HOCKICKOVÁ. Learning experience as a factor of motivation in lower-secondary school in foreign language learning

IN THE $21^{\text {st }}$ CENTURY Vol. 77 , No. 3, 2019

Table 5. Difference of the dimension of learning experience in relation to the associations of the word German.

\begin{tabular}{|c|c|c|c|c|c|c|}
\hline \multicolumn{7}{|c|}{ Negative feelings } \\
\hline $\begin{array}{l}\text { Variable } \\
\text { Mean }\end{array}$ & $\begin{array}{l}\text { Occur-rence } \\
0\end{array}$ & $\begin{array}{l}\text { Occur-rence } \\
1\end{array}$ & Occur-rence $\leq 2$ & $\mathrm{p} /$ Lev. & Anova_F & $\mathrm{p}$ \\
\hline LE & 11.78 & 8.05 & 10 & .798 & 6.464 & $.002^{* *}$ \\
\hline \multicolumn{7}{|c|}{ Complexity } \\
\hline $\begin{array}{l}\text { Variable } \\
\text { Mean }\end{array}$ & $\begin{array}{l}\text { Occur-rence } \\
0\end{array}$ & $\begin{array}{l}\text { Occur-rence } \\
1\end{array}$ & Occur-rence $\leq 2$ & $\mathrm{p} /$ Lev. & Anova_F & $\mathrm{p}$-value \\
\hline LE & 10.92 & 10 & 11.13 & .2405 & .251 & .779 \\
\hline \multicolumn{7}{|c|}{ Foreign Language } \\
\hline $\begin{array}{l}\text { Variable } \\
\text { Mean }\end{array}$ & $\begin{array}{l}\text { Occur-rence } \\
0\end{array}$ & $\begin{array}{l}\text { Occur-rence } \\
1\end{array}$ & Occur-rence $\leq 2$ & $\mathrm{p} /$ Lev. & Anova_F & p-value \\
\hline LE & 10.60 & 11.33 & 10.52 & .2346 & .723 & .488 \\
\hline \multicolumn{7}{|c|}{ German Speaking Countries } \\
\hline $\begin{array}{l}\text { Variable } \\
\text { Mean }\end{array}$ & $\begin{array}{l}\text { Occur-rence } \\
0\end{array}$ & $\begin{array}{l}\text { Occur-rence } \\
1\end{array}$ & Occur-rence $\leq 2$ & p/Lev. & Anova_F & $\mathrm{p}$-value \\
\hline LE & 10.12 & 13.71 & 12 & .191 & 4.538 & $.014^{*}$ \\
\hline
\end{tabular}

Statistical significance at the level $p=.05\left(^{*}\right), p=.01\left(^{* *}\right), p=.001\left(^{* * *}\right)$

$L E$ - learning experience, $p /$ Lev. - significance of Levene's test

\section{Discussion}

The research purpose was to examine motivational structure and its relation to the variable Learning experience of the lower secondary school learners. The idea of early motivation in foreign language education was supported through the research results. In order to motivate students to learn a foreign language, it is essential to get them motivated in early years of studying the language. Therefore, this research focused on the relations between the dimension of learning experience and the other selected motivational structure dimensions, specifically, the years of foreign language study. Moreover, this research conducted qualitative analysis of learning experience in relation to associations with the word German in the selected categories. Firstly, motivational structure of learners was descriptively analysed. The dimensions of Attractivity of language community, Personal goals, and Worries were demonstrated as the most frequent motivational factors in foreign language learning. Based on the findings, the motivational structure of German language learners was mostly extrinsic.

Apparently, it was related to the age and the fact that the respondents were beginners perceiving more the external character of the language and the grammatical structure of the language. The external motivation is considerably important as well as the internal motivation. Deci and Ryan (1993) pointed out the dynamic character of external motivation. Integrated external motivation may become the initial entry into the internal motivation in the later years of foreign language learning. Descriptive analysis of the dimension of learning experience demonstrated almost no importance in the dimension of acceptance of knowledge by the classmates. The relationship to the teacher as well as the feelings of success in the process of learning German language was perceived as average and above average (59.7\% and 58.2\%). Apparently, the personality and the role of a teacher and the feelings of success when learning German language were confirmed as vital in the educational environment of the lower secondary schools. 
Moreover, the research results showed the relations of the dimension of learning experience and the selected dimensions of motivational structure and the years of foreign language studying. The results show that the dimension of learning experience is related to intrinsic motivation, attractivity of language community and personal goals. Based on the correlation analysis, it was supposed that perception of learning experience would be an integral element of the motivational structure tightly related to the dimensions of ideal self, specifically, the images tied to knowledge and the abilities learners desire to have. Although some of the results presented lack of intrinsic motivation in the later years of studying, extrinsic motivation was also absent over the process of studying. Moreover, the results of Riemer $(2003,2010)$ and Juhásová (2016) also emphasised the importance of learning experience and the ideal self in the process of foreign language learning. They claimed that both influence the further stages of foreign language development. They focused on learning experience as a significant dimension in motivational structure of an individual. The research results showed the same significance of learning experience as the results by Riemer (2003, 2010). Apparently, learning experience of a lower secondary school learner (A1 level) is a predictor of their motivational structure. Moreover, the relation between learning experience and the length of study was examined, too. The longer learners study, the less they are motivated to learn the foreign language. Such significant results were found together with Riemer $(2003,2010)$ and Juhásová (2016). They showed the decrease of extent of overall motivation to learning in case of learning experiences in relation to the length of study. A certain negative role is also played by the specific structure of German language. Apparently, it takes longer time from $2-4$ years until the structure of German language is acquired which may cause a decrease of motivation of learners.

Qualitative analysis of the dimension of learning experience in relation to the expression German was carried out in the categories of 1) Complexity, 2) Foreign language, 3) Negative feelings, and 4) German speaking countries. The results manifested the difference between the perception of learning experience in relation to the associations with the expression German. Although, the category German speaking countries was related to the extent of motivation, specifically, to the positive perception of learning experience, the category Negative feelings was related to negative perception of the dimension of learning experience. Probably, the relations between education and reality of German speaking countries increased a positive perception and motivation to learning of German language. The category Negative feelings was related to the dimension of learning experience in case of low level of motivation. Apparently, the respondents perceived German language more as a school subject, than a real need to learn to communicate. They had experienced no real touch with the language outside the school environment; neither had they experienced any touch with the foreign language community. Together with Dörnyei (2014) the results of this research demonstrated the difference between the ideal self and ought-to-self. Although the ideal self is focused on the self-determined achievement of objectives, ought-to-self relates only to its attributions of the expectations of the others and the tasks set by the others. The intentions of the group of learners having the dominant ought-to-self are to have it over, learn, without any specific goal setting. Having intentions in the process of learning appears to be one of the essential factors tightly related to the motivational structure and learning experience of learners. As Dörnyei (2014) suggested motivation relates to positive, long-lasting, and systematic self-determination of individuals. As the results of this research demonstrated, positive self-determination is related to motivation to learn German language supporting positive learning experience.

\author{
PROBLEMS \\ OF EDUCATION \\ IN THE $21^{\text {st }}$ CENTURY \\ Vol. 77, No. 3, 2019 \\ 445
}


Eva STRANOVSKÁ, Anikó FICZERE, Silvia HVOZDÍKOVÁ, Beáta HOCKICKOVÁ. Learning experience as a factor of motivation in lower-secondary school in foreign language learning

\author{
PROBLEMS \\ OF EDUCATION \\ IN THE $21^{\text {st }}$ CENTURY \\ Vol. 77, No. 3, 2019 \\ 446 Conclusions
}

The research results demonstrated learning experience as the essential indicator of motivation to learning foreign languages. Learners considered attractivity of language community, personal goals, and intrinsic motivation as important in the context of foreign language learning. The main contribution of this research was to examine the field of learning motivation in relation to the dimension of learning experience and the other dimensions of motivational structure, specifically, the ideal self in the process of learning German as a foreign language. Considerably, this research brings novelty to the research field of learning experience - as a factor of motivational structure of a foreign language learner - showing that motivation to learn a foreign language in the later years of study does not explicitly relate only to the intrinsic or extrinsic motivation. Many times it is also related to the overall learning experience. Apparently, this dimension of positive learning experience is a predictor of motivational structure of learners-beginners of German language. The results also showed a negative relation between learning experience and the length of FL learning.

Moreover, the research results also supported the hypothesis of difference of perception of learning experience in relation to the perception of the expression German. Although, the category of German speaking countries was related with higher extent of motivation, the expression of negative feelings occurred in relation to the negative perception of learning experience.

Generally, the results of this research contribute to the research in education. The results may also encourage teachers to consider the need for positive learning experience in education. Although strong intrinsic motivation is a positive phenomenon in education, it is necessary to encourage it through reinforcement of external goals and development of positive learning experience in the classroom and overall positive self-determination. The relations between a positive learning experience and the category German speaking countries points out the importance of real-life experience with the target language community and their culture. Such a need of the learners should be reflected in the educational settings.

The current research opened up new research questions. Research of motivation in foreign language learning is a complex phenomenon. Further research should specify those essential predictors of motivation, which are necessary for teachers to develop in the process of education. One of the further research aims, is also to widen qualitative analysis of motivational structure as perceived in the expression German in the further relevant categories. The limitation of this research is the number of the samples therefore, it is necessary to verify the results of this research also in the other regions of the country, as well as the other age groups of the learners.

\title{
Acknowledgements
}

This work was supported by the Slovak Research and Development Agency under the contract No. APVV-17-0071 and National Agency for Research VEGA 1/0062/19.

\section{References}

Butt, A. T., Ahmad, T., \& Ghazala, R. (2010). School and classroom management. Lahore: Majeed Book Depot, Urdu Bazar.

Deci, E. L., \& Ryan, R.M. (1993). Die Selbstbestimmungstheorie der Motivation und ihre Bedetung für die Pädagogik [The self-determination theory of motivation and its relevance to education]. Zeitschrift für Pädagogik, 39(2), 223-238.

Dörnyei, Z. (2001). Motivational strategies in the language classroom. Cambridge: Cambridge University Press. doi: $10.1017 / \mathrm{CBO} 9780511667343$ 
Eva STRANOVSKÁ, Anikó FICZERE, Silvia HVOZDÍKOVÁ, Beáta HOCKICKOVÁ. Learning experience as a factor of motivation in lower-secondary school in foreign language learning

Dörnyei, Z. (2014). Motivation in second language learning. In M. Celce-Murcia, D. M. Brinton \& M. A. Snow (Eds.), Teaching English as second or foreign language (pp. 518-531). Retrieved from http:// www.zoltandornyei.co.uk/uploads/2014-dornyei-cengage.pdf.

Dörnyei, Z., \& Csizér, K. (2002). Some dynamics of language attitudes and motivation: Results of a longitudinal nationwide survey. Applied Linguistics, 23(4), 421-462. Retrieved from http://www. zoltandornyei.co.uk/uploads/2002-dornyei-csizer-al.pdf.

Dunowski, E. (2015). Motivation im fachbezogenen DaF-Unterricht bei tschechischen Studierenden: erste Ergebnisse einer qualitativen Studie [Motivation in subject-related lessons of German as a second language of Czech students: First results of a qualitative study]. In V. Janíková, \& H. Andrášová (Eds.), Deutsch ohne Grenzen: Didaktik Deutsch als Fremdsprache (pp. 108-123). Brno: Tribun.

Gadušová, Z., \& Hašková, A. (2016). Evaluation of teachers' competences as a part of school leadership. In H. Zhang (Ed.), Lecture Notes in Management Science: Vol. 50 (pp. 7-12). Singapore: Singapore Management and Sports Science Institute. doi: 10.5729/1nms.vol50.7

Gadušová, Z., \& Hašková, A. (2017). Results of an on-line survey on competence profiles of primary and secondary school teachers. In W. Fok, \& V. Wenting Li (Eds.), Teaching and Learning with Technology (pp. 271-281). Singapore: World Scientific Publishing.

Gardner, R. C. (1985). Social psychology and second language learning: The role of attitudes and motivation. London: Edward Arnold.

Hašková, A., \& Dovalová, D. (2017). How to evaluate teachers` professional competence. In L. G. Chova, A. L. Martínez, \& I. C. Torres (Eds.), ICERI2017 Proceedings. 10th International Conference of Education, Research and Innovation (pp. 7147-7150). doi: 10.21125/iceri.2017.1910

Janíková, V. (2011). Výuka cizích jazyků [Teaching foreign languages]. Praha: Grada.

Juhásová, J. (2016). Sprachbewusstsein und ihr Einsatz von Jugendlichen, die Deutsch als Tertiärsprache in der Slowakei lernen. [Language awareness and ist use by young people learning German as L3 in Slovakia] Zeitschrift für Interkulturellen Fremdsprachenunterricht, 21(2), 27-41. Retrieved from https://tujournals.ulb.tu-darmstadt.de/index.php/zif/.

Kaliská, L. (2013). Vyučovanie zamerané na učebné štýly. [Learning Styles in Education.] Banská Bystrica: PF UMB.

Kirchner, K. (2004). Motivation beim Fremdsprachenerwerb: Eine qualitative Pilotsudie zur Motivation schwedischer Deutschlerner [Motivation in second language acquisition: A qualitative pilot study to motivation of Swedish learners of German]. Zeitschrift für Interkulturellen Fremdsprachenunterricht, 9(2). Retrieved from https://tujournals.ulb.tu-darmstadt.de/index.php/zif/.

Kondrla, P., \& Králik, R. (2016). Authentic being and moral conscience. European Journal of Science and Theology, 12(4), 155-164.

Králik, R., Lenovsky, L., \& Pavlikova, M. (2018). A few comments on identity and culture of one ethnic minority in Central Europe. European Journal of Science and Theology, 14(6), 63-76.

Lalinská, M. (2014). Between tradition and present: Implementation of folk art and culture into the foreign language education of high school students. In S. Pokrivčáková (Ed.), LLCE2014: Proceedings (pp. 176-187), Nitra: SlovakEdu.

Lalinská, M., \& Scheerová, J. (2014). Kulturologický fenomén l’udového umenia vo vyučovaní francúzskeho jazyka [Culturological phenomenon in folk arts in French language education]. Disputationes scientificae, XIV(4), 35-47.

Masgoret, A. M., \& Gardner, R.C. (2003). Attitudes, motivation and second language learning: A metaanalysis of studies conducted by Gardner and associates. Language Learning, 53(1), 123-163. doi: 10.1111/1467-9922.00227

Oravcová, J. (2000). Psychologické aspekty vizuálnej komunikácie [Psychological aspects of visual communication]. Banská Bystrica: UMB.

Riemer, C. (2003). „Englisch war für mich nur ein Teil meines Stundenplans“ - Motivation zum Englischlernen in Zeiten der Globalisierung [„English was for me only part of my timetable“ - motivation to learn English in the times of globalisation]. Zeitschrift für Interkulturellen Fremdsprachenunterricht, 8(2-3), 72-96.

Riemer, C. (2010). Motivation. In H. Barkowski, \& H.-J. Krumm (Eds.), Fachlexikon Deutsch als Fremdund Zweitsprache. Tübingen, Basel: Francke.

PROBLEMS
OF EDUCATION
IN THE $21^{\text {st }}$ CENTURY
Vol. 77, No. 3, 2019

447 
Eva STRANOVSKÁ, Anikó FICZERE, Silvia HVOZDÍKOVÁ, Beáta HOCKICKOVÁ. Learning experience as a factor of motivation in lower-secondary school in foreign language learning

OF EDUCATION

IN THE $21^{\text {st }}$ CENTURY

Vol. 77, No. 3, 2019

448

Sarmány-Schuller, I. (1992). Kognitívne štýly - súčasný stav a perspektívy [Cognitive Styles - The Current Situation and Perspectives]. In Z. Ruiselová, \& I. Ruisel (Eds.), Praktická inteligencia I. Teoretické a metodologické problémy (pp. 89-106). Bratislava: ÚEP.

Stranovská, E. (2009). Mosty, prieniky a perspektívy efektívneho štúdia I. [Bridges, meeting points and perspectives of effective learning I.]. Nitra: ASPA.

Stranovská, E. (2011). Psycholingvistika: Determinanty osvojovania si a učenia sa cudzieho jazyka a kultúry. [Psycholinguistics: Determinants of foreign language and culture acquisition]. Brno: MSD.

Štúr, M. (2018). Metaphor as a criterium of shifts in understanding language and communication. World Literature Studies, 10(3), 68-85.

Received: April 10, 2019

Accepted: June 15, 2019

\begin{tabular}{|ll|}
$\begin{array}{l}\text { Eva Stranovská } \\
\text { (Corresponding author) }\end{array}$ & $\begin{array}{l}\text { PhD, Associate Professor, Constantine the Philosopher University, Nitra, } \\
\text { Slovakia. } \\
\text { E-mail: estranovska@ukf.sk }\end{array}$ \\
\hline Anikó Ficzere & $\begin{array}{l}\text { PhD. Student, Constantine the Philosopher University in Nitra, Štefánikova } \\
67,94974 \text { Nitra, Slovakia. } \\
\text { E-mail: aniko.ficzere@ukf.sk }\end{array}$ \\
Silvia Hvozdíková & $\begin{array}{l}\text { PhD, Constantine the Philosopher University in Nitra, Štefánikova 67, } 94974 \\
\text { Nitra, Slovakia. }\end{array}$ \\
& E-mail: shozdikova@ukf.sk \\
Beáta Hockicková & PhD, Constantine the Philosopher University in Nitra, Štefánikova 67, 94974 \\
& Nitra, Slovakia. \\
& E-mail: bhockickova@ukf.sk
\end{tabular}

